\title{
Sex-bias in COVID-19: a meta-analysis and review of sex differences in disease and immunity
}

\section{Hannah Peckham}

University College London

Nina de Gruijter

University College London

Charles Raine

University College London

Anna Radziszewska

University College London

Coziana Ciurtin

University College London

Lucy R. Wedderburn

University College London

Elizabeth C. Rosser

University College London

Claire Deakin

University College London

Kate Webb ( $\sim$ kate.webb@uct.ac.za )

University of Cape Town and the Francis Crick Institute https://orcid.org/0000-0003-1087-5946

\section{Systematic Review}

Keywords: sex, COVID-19, immunology

Posted Date: April 20th, 2020

DOl: https://doi.org/10.21203/rs.3.rs-23651/v2

License: @ (i) This work is licensed under a Creative Commons Attribution 4.0 International License.

Read Full License 


\section{Abstract}

A striking anecdotal feature of the Coronavirus disease 2019 (COVID-19) outbreak is the difference in morbidity and mortality between the sexes. Here, we present a meta-analysis of 206, 128 reported cases to demonstrate that whilst there is no difference in the proportion of males and females with confirmed COVID-19, male patients have more than double the odds of requiring intensive treatment unit admission (OR 2.5) and higher odds of death (OR 1.60) when compared to females. We review data revealing how previous Coronavirus outbreaks have demonstrated a similar pattern. Important differences in the immune response to infection exist between sexes, which are likely to contribute to this observation. In this review, we discuss these differences highlighting that females have a more robust innate antiviral response and a better adaptive immune response to infection. An appreciation of how sex is influencing COVID-19 outcomes will have important implications for clinical management and mitigation strategies for this disease.

\section{Introduction}

Anecdotal bias towards male sex has been observed globally in Coronavirus disease 2019 (COVID-19) ${ }^{1}$. Sex is a traditionally under-appreciated biological variable in the immune response to infection, with emerging data highlighting its importance. To address whether the anecdotal bias reported is validated by statistical analysis, we have collected currently available case data and present a meta-analysis to investigate sex as a risk factor for COVID-19 infection, morbidity and mortality. To place this data in context, we have also provided a brief review of the role of sex in previous Coronavirus outbreaks, and more generally in other infections. We also provide a brief up to date overview of the literature that describes the difference in the male and female immune systems, which lead to females mounting a more robust innate and adaptive immune response to viral antigens.

\section{Methods}

\section{Search strategy and selection criteria}

A google search was performed by multiple researchers working remotely for reports on COVID-19 cases that included sex as a variable (Search terms: COVID-19/case/ sex/ country/ data/death/ICU/ITU). Reports were translated using Google translate if they were not in English. Specifically, reports were included if they contained sex as a variable in data describing case number, intensive treatment unit (ITU) admission or mortality. Data were available at the level of summary data representing distinct individuals for each report but not at the level of covariates for all individuals within a study. Consequently, covariates such as lifestyle and comorbidities could not be controlled for. Data are available in Supplementary Table 1. 
Meta-analysis was performed to estimate an overall proportion of male infected cases with $95 \%$ confidence intervals $(\mathrm{Cl})$. This meta-analysis was two-sided and tested the null hypothesis that the proportion of male infected cases was 0.5 . For this analysis, the classic inverse variance method for estimation of single proportions and standard errors was used, which uses logit-transformed proportions. A sensitivity analysis was also performed, in which the generalised linear mixed model (GLMM) method was used to estimate an overall proportion. This yielded identical results, indicating the differing assumptions of these different methods were inconsequential for these data. Meta-analyses were also performed to estimate odds ratios (ORs) with $95 \% \mathrm{Cl}$ associated with male sex for ITU admission and death based on pooled average effect measures that were weighted according to the size and precision of each report. Both of these meta-analyses were two-sided and tested the null hypothesis that the estimated OR was 1 . Fixed and random effects models were estimated and are reported. For all analyses, where parameters and $p$-values differ between fixed and random effects models, the estimates from the random effects model are preferred as these do not assume uniformity across reports and account for variance between reports. Reports that did not contain the data required to calculate ORs were automatically excluded from meta-analyses. Meta-analyses were performed using $\mathrm{R}$ version 3.6.1 and the "meta" package version $4.11-0^{2}$, code available in supplementary material.

\section{Role of the funding source}

The funders of this study had no role in study design, data collection, data analysis, data interpretation, or writing of the report. The corresponding author had full access to all the data in the study and had final responsibility for the decision to submit for publication.

\section{Results}

Forty two reports were found from across the world, from 01.01.2020 up until 30.3.2020 (Fig. 1). Reports were excluded if they did not report the total number of infections by sex (1 ITU case series and 1 mortality case series). One report was excluded as it contained less than 5 cases. Thirty nine reports remained. There were multiple reports originating from China which were carefully examined for duplication. For the analysis of case numbers by sex, 12 reports were excluded due to possible duplication. Of the 39, 6 reports included ITU admission by sex, 1 of these was excluded for possible duplication. Of the 39, 15 reports included mortality by sex, and 3 of these were excluded for possible

duplication. Therefore, altogether 29 reports were included representing 206,128 cases $^{3-31}$. The proportion of male cases with COVID-19 in these reports was only slightly over half at $0.52(95 \% \mathrm{Cl}=$ $0.52,0.53, p=2.3 e-97$ for fixed effects model; $95 \% \mathrm{Cl}=0.50,0.53, p=0.12$ for random effects model) demonstrating that males and females have similar numbers of infections (Fig. 2). Male sex associated with an increased risk of ITU admission (OR $=2.50 ; 95 \% \mathrm{Cl}=2.25,2.78 ; \mathrm{p}=3.8 \mathrm{e}-64$ and $7.3 \mathrm{e}-64$ for fixed and random effects models, respectively; $n=43,075$ ) (Fig. 3). Male sex also associated with an increased risk of mortality $(\mathrm{OR}=1.62,95 \% \mathrm{Cl}=1.54,1.71, \mathrm{p}=5.5 \mathrm{e}-77$ for fixed effect model; $\mathrm{OR}=1.60$, $95 \% \mathrm{Cl}=1.41,1.82, p=7.4 \mathrm{e}-13$ for random effects model; $n=170,983)$ (Fig. 4). 


\section{Discussion}

These data show no difference in the proportion of COVID-19 infected cases between sexes, but highlight that male sex associates significantly with morbidity (ITU admission OR 2.50) and mortality (OR 1.60). Due to the nature of these rapidly acquired data, the age and comorbidity for individual cases are not available. This limits our ability to accurately predict the role of sex in disease without adjusting for these factors, as certain comorbidities might associate with sex. Once more data become available, future studies will be able to adjust for additional factors using techniques such as mediation analysis. In addition, all reports did not use the same COVID-19 tests (with differing sensitivity and specificity) and different population groups were included in each report (e.g. hospital admissions vs community cases). Despite these limitations, these data highlight an important trend in the epidemiology of COVID-19, with male sex acting as a risk factor for severe disease.

Gendered differences in social activity and behaviours could contribute to the sex difference seen in COVID-19 disease severity. In China, $50.5 \%$ of men versus only $2.1 \%$ of women smoke ${ }^{32}$, although smoking has not yet emerged as a clear risk factor for severe disease ${ }^{33}$. Early data from the COVID-19 outbreak in China indicate that hypertension and diabetes are the most common comorbidities in hospitalised patients ${ }^{34}$. Globally from age $45-54$, it is estimated that $33 \%$ of women compared to $36 \%$ of men are hypertensive, with this ratio reversing in the elderly $(>75)$, where it is estimated that $81 \%$ of women and $73 \%$ of men are hypertensive ${ }^{35}$. Similarly in diabetes, it is estimated that globally $9.0 \%$ of women and $9.6 \%$ of men are diabetic, and this ratio tends to increase and reverse in the elderly ${ }^{36}$. Men are less likely to wash their hands with soap after entering a restroom ${ }^{37}$ and in many cultures men may be more likely to leave the house and enter crowded areas. Our data however shows no difference in the numbers of infected cases between the sexes, so sex difference in hygiene behaviour is unlikely to explain the sex difference in disease severity. There may be non-immunological biological differences between sexes that play a role. For example, COVID-19 most likely binds to angiotensin converting enzyme 2 (ACE2) receptors facilitating viral entry and human to human transmission ${ }^{38}$. Pre-print studies are conflicting as to whether ACE2 expression in lung tissue is different between sexes ${ }^{39,40}$. Therefore, these factors are unlikely to fully explain the stark sex inequality in morbidity and mortality associated with COVID-19. Fundamental differences in the immune response to infection between sexes are more likely to contribute to this phenomenon. Below, we review literature pertaining to the sex differences seen in previous Coronavirus outbreaks, other infections and the known sex differences in the immune system.

\section{Review Of Sex Bias In Infection And Immunity}

\section{SEX DIFFERENCE IN PREVIOUS CORONAVIRUS OUTBREAKS}

-HUMANS: Severe Acute Respiratory Syndrome Coronavirus 1 (SARS-CoV-1) showed a similar sex discrepancy in the 2003 epidemic. In Hong Kong, the case fatality rate was $13.2 \%$ for females $(95 \% \mathrm{Cl}=$ $11.1,15.3)$ and $21.9 \%$ for males $(95 \% \mathrm{Cl}=19.0,24.8)$, with an age-adjusted relative mortality risk ratio of 
$1.62(95 \% \mathrm{Cl}=1.21,2.16)$ for males ${ }^{41}$. In a study in Singapore during the same outbreak, male sex associated with an odds ratio of $3.10(95 \% \mathrm{Cl}=1.64,5.87 ; \mathrm{p}=<0.001)$ for ITU admission or death ${ }^{42}$. A retrospective analysis of the Saudi Arabian Middle East Respiratory Syndrome (MERS) outbreak in 2013 2014 showed a case fatality rate of $52 \%$ in men and $23 \%$ in women ${ }^{43}$.

-ANIMALS: This sex bias is also observed in animal models of SARS infections. In a mouse model of SARS-CoV-1 infection, female mice had a lower case fatality ratio, and less lung inflammation and oedema than males. Moreover, ovarectomy and treatment with the oestradiol antagonist, ICI 182, 780, diminished the sex advantage of female mice, implicating oestradiol in this sex difference ${ }^{44}$. Studies in animals that are known vectors for human disease have not shown the same sex bias that is observed in humans. Seropositivity in these reservoir animals, which act as hosts for viral pathogens but generally do not display symptoms, has been investigated with sampling studies. Studies in wild bats, known

reservoirs for pathogenic coronaviruses, have shown either similar seropositivity in males and females ${ }^{45}$, or higher seropositivity in female animals ${ }^{46}$. Similar studies in dromedary camels, the main reservoir host for MERS-CoV, showed higher seropositivity in females ${ }^{47,48}$. A possible explanation for the higher rate of seropositivity in females is the higher risk of exposure: the close proximity of female dromedaries to their highly susceptible calves puts them at repeated risk of infection ${ }^{48}$, while pregnant bats collect to stay warm during roosting season ${ }^{46}$.

\section{SEX DIFFERENCES IN OTHER INFECTIONS}

Sex differences in response to infection occur at all ages with a generally higher burden of bacterial, viral, fungal and parasitic infections in human males. New-born males are more likely to die from infection than females ${ }^{49}$ and male children have higher rates of parasitic infections ${ }^{50}$. Tuberculosis and hepatitis $\mathrm{B}$ infection are more common in males, who are also more likely to die of sepsis than females ${ }^{51,52}$. An exception to this male predominance in infectious disease is urinary tract infections, where adult females are 40 times more likely than males to develop disease ${ }^{53}$. Females with human immunodeficiency virus (HIV) infection have less circulating viral RNA, but are 1.6 times more likely to progress to advanced immune deficiency syndrome (AIDS) at the same viral load as men $^{54}$. Women are more susceptible to infections of the upper respiratory tract such as tonsillitis and sinusitis while men are more susceptible to lower respiratory tract infections i.e. community-acquired pneumonia ${ }^{55}$. Notably, the female sex bias in infection is mainly observed after puberty and before menopause, suggesting that sex hormones play an important role in this phenomenon ${ }^{53}$.

\section{SEX DIFFERENCES IN INFLUENZA}

Unlike COVID-19, mortality rates during previous influenza pandemics have typically been higher in females, despite a higher prevalence of infection in men. Studies from Japan during the most recent H1N1 pandemic found that during reproductive years morbidity rates were higher in females, but 
outcomes were worse for males under 20 and over $80^{56}$. Pregnancy is an established risk factor for influenza morbidity and mortality: in US data from the 2009 Influenza A (H1N1) pandemic, pregnant women represented $5 \%$ of all deaths despite comprising less than $1 \%$ of the population ${ }^{57}$. From the limited data about COVID-19 in pregnancy to date, there does not seem to be the same association with morbidity that is seen in influenza, but this may change as more information becomes available ${ }^{58}$. Data from influenza-infected animal models demonstrate no difference in viral load between males and females, but greater pro-inflammatory cytokine and chemokine production in females, suggesting that host-mediated inflammatory responses contribute to the disparity in morbidity between the sexes ${ }^{59}$. Analysis of the effect of sex hormones versus the sex chromosome complementon the response to influenza infection demonstrates that sex steroids are likely to be driving the differences observed ${ }^{59}$.

The stronger female response to influenza antigens that may underlie more severe disease is mirrored in the female response to vaccination. Women consistently report more severe local and systemic side effects and produce higher antibody titres in response to seasonal flu vaccinations ${ }^{60,61}$ than men. Females achieved equivalent protective antibody titres to males at half the dose of inactivated influenza vaccine ${ }^{62}$. After influenza vaccination, female $B$ cells produced more antigen-specific lgG, mediated by sex-based differences in gene expression within B cells ${ }^{63}$.

\section{SEX DIFFERENCES IN THE IMMUNE SYSTEM}

Despite being a previously underappreciated biological variable, it is now well established that males and females mount different immune responses to infection. Whilst some differences are seen in the immune response from birth, certain differences are only observed after sexual maturity. This suggests that both sex chromosome complement as well as sex hormones influence the immune response. In very general terms, females tend to be skewed towards a more robust immune response towards pathogens with relatively decreased self-tolerance, whereas males tend to have better self-tolerance, but a less robust response to pathogens. This contributes to the clinical phenotype of females being relatively protected against infection and malignancy when compared to males, but more prone to developing autoimmune diseases.

SEX CHROMOSOMES AND SEX HORMONES: There is an over-expression of genes with an immune function on the $X$ chromosome ${ }^{64}$, as evidenced by the existence of many $X$-linked immunodeficiency disorders ${ }^{65}$. There is emerging evidence that there may be variable inactivation and regulation of the inactive $X$ chromosome in immune cells with subsequent bi-allelic expression of $X$-encoded immune genes in females ${ }^{66,67}$. Many immune cells express oestrogen receptors alpha and beta ${ }^{68}$. The effect of oestradiol seems to be dose-dependent, with low doses corresponding to a T helper 1 (Th1)-type response and cell-mediated immunity, and higher doses (such as in pregnancy) corresponding to T helper 2 (Th2)type responses and humoral immunity ${ }^{51,69}$. Oestradiol modulates CD4 T cells and CD8 T cells ${ }^{70}$, promotes $\mathrm{T}$ regulatory (Treg) cell expansion in vitro and in vivo ${ }^{71}$ and decreases T helper 17 
(Th17)/interleukin-17 (IL-17) production ${ }^{72}$. Oestradiol is associated with increased antibody production, somatic hyper-mutation and class switching ${ }^{73}$, abundance of neutrophils ${ }^{74}$, and monocyte/macrophage cytokine production ${ }^{75}$. In human T cells, almost half of the activated genes have an oestrogen response element in their promoter region ${ }^{76}$. Testosterone is generally thought to dampen the immune response; a lack of testosterone associates with increased inflammatory cytokines, antibody titres, CD4/CD8 ratios and natural killer cells along with a decrease in Treg cells 51,77 .

INNATE IMMUNITY: In terms of innate immunity, limited data suggest sex-based differences in the expression and response of pattern-recognition receptors on various immune cells. For example, both neutrophils from human males and peritoneal macrophages from male mice express higher levels of tolllike receptor 4 (TLR4) ${ }^{78,79}$ and produce higher levels of tumour necrosis factor alpha (TNFa) after lipopolysaccharide (LPS) stimulation than females ${ }^{80}$.

There are important sex differences in the innate antiviral response that may be relevant to the sex discrepancy seen in COVID-19. There is a large body of evidence showing that females have a more robust production of type 1 interferon (IFN) upon sensing of viral RNA via toll-like receptor 7 (TLR7) ${ }^{81-86}$. When exposed to HIV-derived RNA, plasmacytoid dendritic cells from females produce more type 1 IFN than males ${ }^{87}$. This phenomenon has been shown to associate with sex hormone concentration but also the number of $X$ chromosomes present 8284 .

ADAPTIVE IMMUNITY: The adaptive immune system mirrors the trend of females being skewed towards a more robust immune response, but poorer self-tolerance, and males having improved tolerance, but a less robust response to infections. Autoimmune regulator (AIRE) gene expression is decreased in female thymic tissue compared to males and females have improved thymic function when compared to males throughout life ${ }^{88-90}$. At all ages, and even during HIV infection, females have more CD4+ $T$ cells than males ${ }^{91-96}$. Female $T$ cells have more robust cytotoxic activity and upregulation of inflammatory genes than males ${ }^{75}$, while males have more Tregs than females ${ }^{97}$. Females have more $B$ cells and produce more immunoglobulin than males ${ }^{91,98}$.

\section{SEX DIFFERENCE IN IMMUNE-AGING}

There is a marked association between morbidity/mortality and advanced age in COVID-19. Although age-associated changes in immunity are beyond the scope of this review and are available elsewhere ${ }^{99}$, it is of note that age-associated changes in the immune system are also different between sexes. There is a male-specific, age-associated decline in B cells and a trend towards accelerated immune ageing in males 100,101 which may further add to the sex difference in disease phenotype.

\section{Conclusion}


These data demonstrate that although there is no sex difference in the proportion of people infected with COVID-19, men are at a significantly higher risk of severe disease and death than women. Previous reports describe fundamental differences between sexes in the immune response to infection. These include a more robust antiviral innate interferon response and increased adaptive immunity towards viral antigens in females. In people infected with COVID-19, these differences are likely to lead to more effective viral control in females, which may contribute to the relatively lower risk of developing severe disease. Although further studies are needed, these data have implications for the clinical management of COVID-19 and highlight the importance of considering sex as an important variable in fundamental and clinical research.

\section{Declarations}

\section{ACKNOWLEDGEMENTS}

KW is funded by the Crick African Network, African Career Accelerator Award (CANB0001/01). This work is funded by a Centre of Excellence (Centre for Adolescent Rheumatology Versus Arthritis) grant to LRW (21593) as well as grants from Medical Research Council (MR/R013926/1) and Great Ormond Street Children's Charity to LRW. ECR and NdG are supported by a Medical Research Foundation Lupus Fellowship to ECR (MRF-057-0001-RG-ROSS-C0797). LRW is supported by the NIHR Biomedical Research Centre at Great Ormond Street Hospital. HP is supported by a Versus Arthritis Studentship to CC (22203).

$\mathrm{KW}$ would like to thank this exceptional team for their dedication to getting these vital data gathered quickly and efficiently, with many working remotely, working on the frontline and some working while unwell in quarantine

\section{Declaration of interests}

We declare no competing interests

\section{Contributions:}

$\mathrm{KW}, \mathrm{ECR}, \mathrm{HP}, \mathrm{NMdG}, \mathrm{AR}, \mathrm{CR}$ wrote the manuscript. CD analysed data, provided the statistical analysis, figures and contributed to the manuscript. ECR edited figures. HP, NMdG, AR, CR searched, evaluated and gathered data. CC and LRW edited and contributed to the manuscript.

\section{References}

1. Devlin H. Men are much more likely to die from coronavirus - but why? https://www.theguardian.com/world/2020/mar/26/men-are-much-more-likely-to-die-fromcoronavirus-but-why (accessed 02-04-2020 2020) (2020) 
2. Balduzzi, S., Rücker, G. and Schwarzer, G. How to perform a meta-analysis with R: a practical tutorial. Evid-Based Ment. Health, 22(4):153-160 (2019)

3. Department of Health Australia. Number of notifications of COVID-19, Australia, 2020 by age group and sex. Australia (2020)

4. L'institut de Santé Sciensano. COVID-19 - BULLETIN EPIDEMIOLOGIQUE DU 27 MARS 2020. Belgium (2020)

5. Government of Canada. Epidemiological summary of COVID-19 cases in Canada. Canada (2020)

6. Yang X, Yu Y, Xu J, et al. Clinical course and outcomes of critically ill patients with SARS-CoV-2 pneumonia in Wuhan, China: a single-centered, retrospective, observational study. The Lancet Respir Med; published online February 24. DOI: 10.1016/S2213-2600(20)30079-5 (2020)

7. China CDC Weekly. Vital Surveillances: The Epidemiological Characteristics of an Outbreak of 2019 Novel Coronavirus Diseases (COVID-19) - China, 2020. China; 2: 113-22 (2020)

8. Wang D, Hu B, Hu C, et al. Clinical Characteristics of 138 Hospitalized Patients With 2019 Novel Coronavirus-Infected Pneumonia in Wuhan, China. JAMA; 323(11): 1061-9 (2020)

9. Statens Serum Institut. COVID-19 i Danmark Epidemiologisk overvågningsrapport. 26-03-2020 data opdateret kl. 08:00. Denmark (2020)

10. Santé Publique France. COVID-19: epidemiological update of March 15, 2020. France (2020)

11. Robert Koch Institut. Täglicher Lagebericht des RKI zur Coronavirus-Krankheit-2019 (COVID-19) 20.03.2020 - AKTUALISIERTER STAND FÜR DEUTSCHLAND. Germany (2020)

12. Purdie A, Hawkes S, Buse K, et al. Sex, gender and COVID-19: Disaggregated data and health disparities, 24/03/2020. https://blogs.bmj.com/bmjgh/2020/03/24/sex-gender-and-covid-19disaggregated-data-and-health-disparities/ (accessed 26/3/2020) (2020)

13. Istituto Superiore di Sanità. Epidemia COVID-19 Aggiornamento nazionale 19 marzo 2020 - ore 16:00. Italy (2020)

14. Rijksinstituut voor Volksgezondheid en Milieu. Epidemiologische situatie COVID-19 in Nederland 23 maart 2020. The Netherlands (2020)

15. COVID-19 Dagsrapport onsdag 25. mars 2020. Norway (2020)

16. Ministério da Saúde. NOVO CORONAVÍRUS COVID-19 RELATÓRIO DE SITUAÇÃO. Portugal (2020)

17. Updates on COVID-19 in Republic of Korea - 27 March, 2020. Republic of Korea (2020)

18. Ministerio de Sanidad. Actualización n 56. Enfermedad por el coronavirus (COVID-19) 26.03.20. Spain (2020)

19. Maladie à coronavirus 2019 (COVID-19) Rapport sur la situation épidémiologique en Suisse et dans la rincipauté de Liechtenstein. Switzerland (2020)

20. Department of Health Ireland. Statement from the National Public Health Emergency Team Wednesday 25 March. Ireland (2020)

21. Ministerio de Salud. Casos COVID-19 en Chile. Chile (2020)

22. Folkhälsomyndigheten. Veckorapport om covid-19, vecka 11. Sweden (2020) 
23. Terveyden ja hyvinvoinnin laitos. Ajantasaista tietoa koronaviruksesta COVID-19. Finland (2020)

24. MZČR. COVID-19: Aktuální počty onemocnění koronavirem v ČR. Czech Republic (2020)

25. Analiza cazuri confirmate (261) pana la 1803 2020. Romania (2020)

26. Amtliches Dashboard COVID19 - öffentlich zugängliche Informationen. Austria (2020)

27. Ministry of Health Saudi Arabia. COVID-19 Follow-up Committee Reviews Latest Updates of the Fight Against the Pandemic. Saudi Arabia (2020)

28. Koroonakart -Information about Coronavirus Disease COVID 19. Estonia (2020)

29. Department of Health Republic of Philippines. COVID-19 Case Tracker. Republic of Philippines (2020)

30. Ministry of Health NZ. COVID-19- Current Cases. New Zealand (2020)

31. Nacionalni institut za javno zdravje. Dnevno spremljanje okužb s SARS-CoV-2 (COVID-19). Slovenia (2020)

32. Global Adult Tobacco Survey, Fact Sheet China, 2018. https://www.who.int/docs/defaultsource/wpro--documents/countries/china/2018-gats-china-factsheet-cn-en.pdf?sfvrsn=3f4e2da9_2 (accessed 25/3/20) (2018)

33. Cai H. Sex difference and smoking predisposition in patients with COVID-19. The Lancet Respir Med 8(4):e20 (2020)

34. Guan W-j, Liang W-h, Zhao Y, et al. Comorbidity and its impact on 1590 patients with Covid-19 in China: A nationwide analysis. Eur Respir J, published online April 01. DOI 10.1183/13993003.00547$2020(2020)$

35. Benjamin EJ, Blaha MJ, Chiuve SE, et al. Heart disease and stroke statistics-2017 Update: a report from the American Heart Association. Circulation, 135(10): e146-e603 (2017)

36. Saeedi P, Petersohn I, Salpea P, et al. Global and regional diabetes prevalence estimates for 2019 and projections for 2030 and 2045: Results from the International Diabetes Federation Diabetes Atlas, 9(th) edition. Diabetes Res Clin Pract, 157: 107843 (2019)

37. Judah G, Aunger R, Schmidt W-P, Michie S, Granger S, Curtis V. Experimental pretesting of handwashing interventions in a natural setting. Am j of public health, 99 Suppl 2: S405-S11 (2009)

38. Wan Y, Shang J, Graham R, Baric RS, Li F. Receptor recognition by the novel Coronavirus from Wuhan: an analysis based on decade-long structural studies of SARS Coronavirus. J of Virol, 94(7): e00127-20 (2020)

39. Cai G. Bulk and single-cell transcriptomics identify tobacco-use disparity in lung gene expression of ACE2, the receptor of 2019-nCov. medRxiv published online February 02, DOI: 2020.02.05.20020107 (2020)

40. Zhao Y, Zhao Z, Wang Y, Zhou Y, Ma Y, Zuo W. Single-cell RNA expression profiling of ACE2, the putative receptor of Wuhan 2019-nCov. bioRxiv published online January 26, DOI:2020.01.26.919985 (2020)

41. Karlberg J, Chong DS, Lai WY. Do men have a higher case fatality rate of severe acute respiratory syndrome than women do? Am J Epidemiol 159(3): 229-31 (2004) 
42. Leong HN, Earnest A, Lim HH, et al. SARS in Singapore-predictors of disease severity. Ann Acad Med Singapore 35(5): 326-31 (2006)

43. Alghamdi IG, Hussain, II, Almalki SS, Alghamdi MS, Alghamdi MM, El-Sheemy MA. The pattern of Middle East respiratory syndrome coronavirus in Saudi Arabia: a descriptive epidemiological analysis of data from the Saudi Ministry of Health. Int J Gen Med 7:417-23 (2014)

44. Channappanavar R, Fett C, Mack M, Ten Eyck PP, Meyerholz DK, Perlman S. Sex-based differences in susceptibility to Severe Acute Respiratory Syndrome Coronavirus Infection. J Immunol 198(10): 4046-53 (2017)

45. Wacharapluesadee $S$, Duengkae $P$, Chaiyes $A$, et al. Longitudinal study of age-specific pattern of coronavirus infection in Lyle's flying fox (Pteropus lylei) in Thailand. Virol J 15(1): 38 (2018)

46. Rizzo F, Edenborough KM, Toffoli R, et al. Coronavirus and paramyxovirus in bats from Northwest Italy. BMC Vet Res 13(1): 396 (2017)

47. Zohaib A, Saqib M, Athar MA, et al. Countrywide survey for MERS-Coronavirus antibodies in dromedaries and humans in Pakistan. Virol Sin 33(5): 410-7 (2018)

48. Sayed AS, Malek SS, Abushahba MF. Seroprevalence of Middle East Respiratory Syndrome Corona virus in dromedaries and their traders in upper Egypt. J Infect Dev Ctries 14(2): 191-8 (2020)

49. Sawyer CC. Child mortality estimation: estimating sex differences in childhood mortality since the 1970s. PLoS Med 9(8): e1001287 (2012)

50. Flanagan KL, Jensen KJ. Sex Differences in Outcomes of Infections and Vaccinations in Under FiveYear-Old Children. In: Klein SL, Roberts CW, eds. Sex and Gender Differences in Infection and Treatments for Infectious Diseases. Springer International Publishing, Cham; 273-312 (2015)

51. Klein SL, Flanagan KL. Sex differences in immune responses. Nat Rev Immunol 16(10): 626-38 (2016)

52. Schroder J, Kahlke V, Staubach KH, Zabel P, Stuber F. Gender differences in human sepsis. Arch Surg 133(11): 1200-5 (1998)

53. Zychlinsky Scharff A, Rousseau M, Lacerda Mariano L, et al. Sex differences in IL-17 contribute to chronicity in male versus female urinary tract infection. JCI Insight 4(13):e122998 (2019)

54. Griesbeck M, Scully E, Altfeld M. Sex and gender differences in HIV-1 infection. Clin Sci 130(16): 1435-51 (2016)

55. Falagas ME, Mourtzoukou EG, Vardakas KZ. Sex differences in the incidence and severity of respiratory tract infections. Respir med 101(9): 1845-63 (2007)

56. Eshima N, Tokumaru O, Hara S, et al. Sex- and age-related differences in morbidity rates of 2009 pandemic influenza A H1N1 virus of swine origin in Japan. PLoS One 6(4): e19409 (2011)

57. Siston AM, Rasmussen SA, Honein MA, et al. Pandemic 2009 influenza A(H1N1) virus illness among pregnant women in the United States. JAMA 303(15): 1517-25 (2010)

58. Guan W-j, Ni Z-y, Hu Y, et al. Clinical characteristics of coronavirus disease 2019 in China. N. Engl. (2020) 
59. Klein SL, Hodgson A, Robinson DP. Mechanisms of sex disparities in influenza pathogenesis. J Leukoc Biol, 67-73 (2012)

60. Cook MB, McGlynn KA, Devesa SS, Freedman ND, Anderson WF. Sex disparities in cancer mortality and survival. Cancer Epidemiol Biomarkers Prev 20(8): 1629-37 (2011)

61. Flanagan KL, Fink AL, Plebanski M, Klein SL. Sex and gender differences in the outcomes of vaccination over the life course. Annu Rev Cell Dev Biol. 33: 577-99 (2017)

62. Engler RJ, Nelson MR, Klote MM, et al. Half- vs full-dose trivalent inactivated influenza vaccine (20042005): age, dose, and sex effects on immune responses. Arch Intern Med. 168(22): 2405-14 (2008)

63. Voigt EA, Ovsyannikova IG, Kennedy RB, et al. Sex Differences in Older Adults' Immune Responses to Seasonal Influenza Vaccination. Front Immunol 10(180) (2019)

64. Spolarics Z, Pena G, Qin Y, Donnelly RJ, Livingston DH. Inherent X-Linked Genetic Variability and Cellular Mosaicism Unique to Females Contribute to Sex-Related Differences in the Innate Immune Response. Front Immunol 8:1455 (2017)

65. Bianchi I, Lleo A, Gershwin ME, Invernizzi P. The X chromosome and immune associated genes. J Autoimmun. 38(2-3): J187-J92 (2012)

66. Qu K, Zaba LC, Giresi PG, et al. Individuality and variation of personal regulomes in primary human T cells. Cell Syst 1(1): 51-61 (2015)

67. Wang J, Syrett CM, Kramer MC, Basu A, Atchison ML, Anguera MC. Unusual maintenance of $X$ chromosome inactivation predisposes female lymphocytes for increased expression from the inactive X. 113(14):E2029-38 (2016)

68. Phiel KL, Henderson RA, Adelman SJ, Elloso MM. Differential estrogen receptor gene expression in human peripheral blood mononuclear cell populations. Immunol Lett 97(1): 107-13 (2005)

69. Straub RH. The complex role of estrogens in inflammation. Endocr Rev 28(5): 521-74 (2007)

70. Khan D, Ansar Ahmed S. The immune system is a natural target for estrogen action: opposing effects of estrogen in two prototypical autoimmune diseases. Front Immunol 6:635 (2015)

71. Polanczyk MJ, Carson BD, Subramanian S, et al. Cutting edge: estrogen drives expansion of the CD4+CD25+ regulatory T cell compartment. J Immunol 173(4): 2227-30 (2004)

72. Tyagi AM, Srivastava K, Mansoori MN, Trivedi R, Chattopadhyay N, Singh D. Estrogen deficiency induces the differentiation of IL-17 secreting Th17 cells: a new candidate in the pathogenesis of osteoporosis. PLoS One 7(9): e44552 (2012)

73. Pauklin S, Sernandez IV, Bachmann G, Ramiro AR, Petersen-Mahrt SK. Estrogen directly activates AID transcription and function. J Exp Med 206(1): 99-111 (2009)

74. Jilma B, Department of Clinical Pharmacology UoV, Austria., Eichler HG, et al. Effects of 17 betaestradiol on circulating adhesion molecules. J Clin Endocrinol Metab 79(6): 1619-24 (2018)

75. Bouman A, Heineman MJ, Faas MM. Sex hormones and the immune response in humans. Hum Reprod Update 11(4): 411-23 (2005) 
76. Hewagama A, Patel D, Yarlagadda S, Strickland FM, Richardson BC. Stronger inflammatory/cytotoxic T-cell response in women identified by microarray analysis. Genes Immun 10(5): 509-16 (2009)

77. Page ST, Plymate SR, Bremner WJ, et al. Effect of medical castration on CD4+CD25+ T cells, CD8+ T cell IFN-y expression, and NK cells: a physiological role for testosterone and/or its metabolites. Am J Physiol Endocrinol Metab 290(5):E856-63 (2006)

78. Aomatsu M, Kato T, Kasahara E, Kitagawa S. Gender difference in tumor necrosis factor-alpha production in human neutrophils stimulated by lipopolysaccharide and interferon-gamma. Biochem Biophys Res Commun 441(1): 220-5 (2013)

79. Marriott I, Bost KL, Huet-Hudson YM. Sexual dimorphism in expression of receptors for bacterial lipopolysaccharides in murine macrophages: a possible mechanism for gender-based differences in endotoxic shock susceptibility. J Reprod Immunol 71(1): 12-27 (2006)

80. Moxley G, Posthuma D, Carlson P, et al. Sexual dimorphism in innate immunity. Arthritis Rheum 46(1): 250-8 (2002)

81. Berghöfer B, Frommer T, Haley G, Fink L, Bein G, Hackstein H. TLR7 Ligands Induce Higher IFN-a Production in Females. J Immunol 177(4): 2088-96 (2006)

82. Laffont $\mathrm{S}$, Rouquié $\mathrm{N}$, Azar $\mathrm{P}$, et al. X-chromosome complement and estrogen receptor signaling independently contribute to the enhanced TLR7-mediated IFN-a production of plasmacytoid dendritic cells from women. J Immunol 193(11): 5444-52 (2014)

83. Seillet $C$, Laffont $S$, Trémollières $F$, et al. The TLR-mediated response of plasmacytoid dendritic cells is positively regulated by estradiol in vivo through cell-intrinsic estrogen receptor a signaling. Blood 119(2): 454-64 (2012)

84. Webb K, Peckham H, Radziszewska A, et al. Sex and pubertal differences in the type 1 interferon pathway associate with both $\mathrm{x}$ chromosome number and serum sex hormone concentration. Front Immunol 9:3167 (2018)

85. Ziegler SM, Altfeld M. Human Immunodeficiency Virus 1 and Type I Interferons-Where Sex Makes a Difference. Front Immunol 8:1224 (2017)

86. Ziegler SM, Beisel C, Sutter K, et al. Human pDCs display sex-specific differences in type I interferon subtypes and interferon alpha/beta receptor expression. Eur J Immunol 47(2): 251-6 (2017)

87. Meier A, Chang JJ, Chan ES, et al. Sex differences in the Toll-like receptor-mediated response of plasmacytoid dendritic cells to HIV-1. Nat Med 15(8): 955-9 (2009)

88. Dragin N, Bismuth J, Cizeron-Clairac G, et al. Estrogen-mediated downregulation of AIRE influences sexual dimorphism in autoimmune diseases. J Clin Invest 126(4):1525-37 (2016)

89. Zhu ML, Bakhru P, Conley B, et al. Sex bias in CNS autoimmune disease mediated by androgen control of autoimmune regulator. Nat Commun 7: 11350 (2016)

90. Clave E, Araujo IL, Alanio $\mathrm{C}$, et al. Human thymopoiesis is influenced by a common genetic variant within the TCRA-TCRD locus. Sci Transl Med 10(457): eaao2966 (2018) 
91. Abdullah M, Chai P-S, Chong M-Y, et al. Gender effect on in vitro lymphocyte subset levels of healthy individuals. Cell Immunol 272(2): 214-9 (2012)

92. Lee BW, Yap HK, Chew FT, et al. Age- and sex-related changes in lymphocyte subpopulations of healthy Asian subjects: from birth to adulthood. Cytometry 26(1): 8-15 (1996)

93. Lisse IM, Aaby P, Whittle H, Jensen H, Engelmann M, Christensen LB. T-lymphocyte subsets in West African children: impact of age, sex, and season. J Pediatr 130(1): 77-85 (1997)

94. Delmas MC, Jadand C, De Vincenzi I, et al. Gender difference in CD4+ cell counts persist after HIV-1 infection. SEROCO Study Group. AIDS 11(8): 1071-3 (1997)

95. Mori M, Adland E, Paioni P, et al. Sex differences in antiretroviral therapy initiation in pediatric HIV infection. PLoS One 10(7): e0131591 (2015)

96. Ruel TD, Zanoni BC, Ssewanyana I, et al. Sex differences in HIV RNA level and CD4 cell percentage during childhood. Clin Infect Dis 53(6): 592-9 (2011)

97. Afshan G, Afzal N, Qureshi S. CD4+CD25(hi) regulatory T cells in healthy males and females mediate gender difference in the prevalence of autoimmune diseases. Clin Lab 58(5-6): 567-71 (2012)

98. Stoica G, Macarie E, Michiu V, Stoica RC. Biologic variation of human immunoglobulin concentration. I. Sex-age specific effects on serum levels of IgG, IgA, IgM and IgD. Med Interne 18(3): 323-32 (1980)

99. Fulop T, Larbi A, Dupuis G, et al. Immunosenescence and inflamm-aging as two sides of the same coin: friends or foes? Front Immunol 8: 1960 (2017)

100. Márquez EJ, Chung C-h, Marches R, et al. Sexual-dimorphism in human immune system aging. Nat Comms 11(1): 751 (2020)

101. Gubbels Bupp MR, Potluri T, Fink AL, Klein SL. The confluence of sex hormones and aging on immunity. Front Immunol 9: 1269 (2018)

\section{Figures}



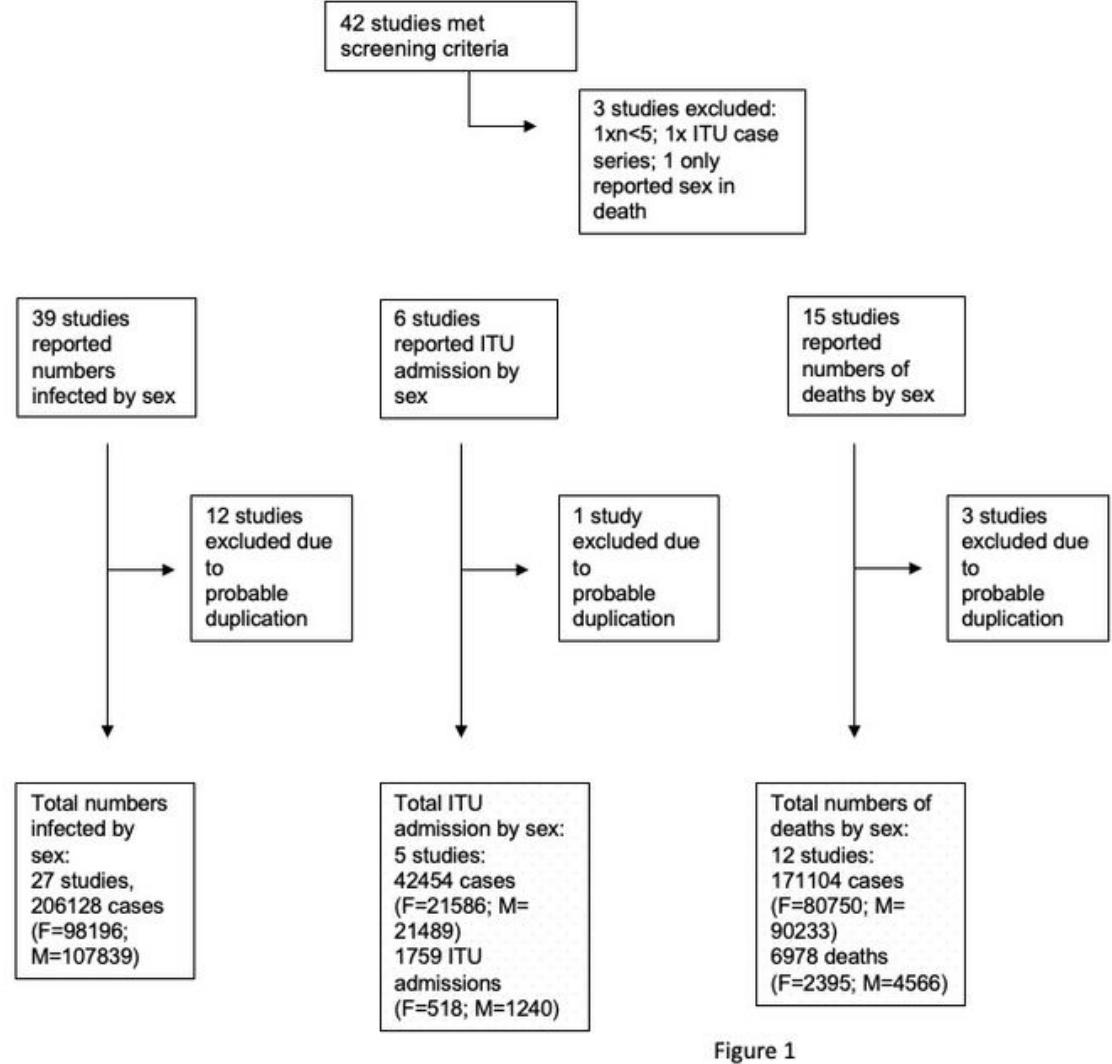

\section{Figure 1}

Study selection. 42 reports were found. 2 reports were excluded as they did not report the total number of infections by sex (1 ITU admission only case series and 1 mortality case series)and 1 report was excluded as it contained less than 5 cases. Of the 39 remaining reports; for the analysis of case numbers by sex, 12 reports were excluded due to possible duplication; of the 6 reports that reported ITU admission 
by sex, 1 was excluded for possible duplication; of the 15 reports that included mortality by sex, 3 were excluded for possible duplication.

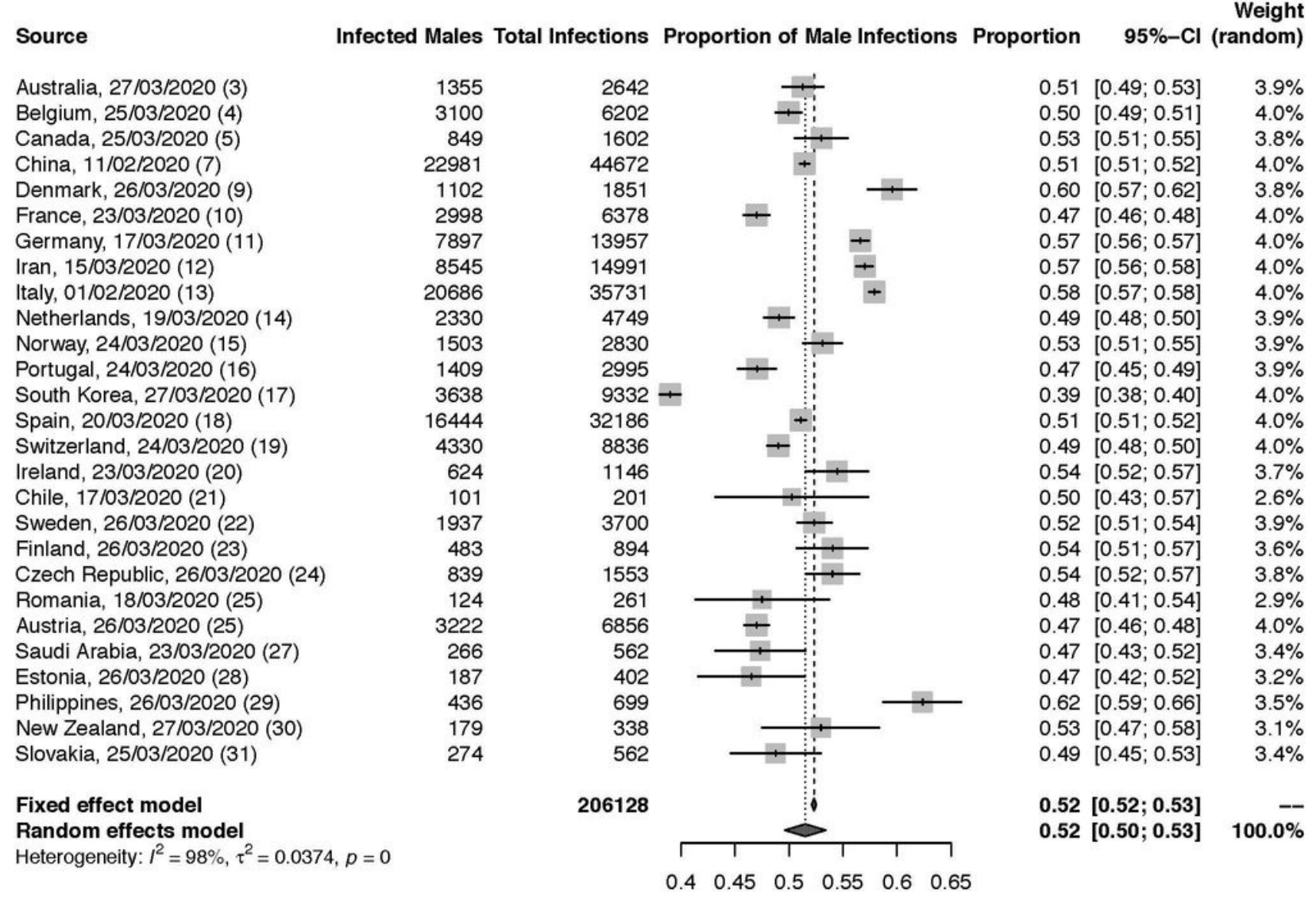

Figure 2

There is no obvious sex difference in the proportion of people infected with COVID-19. Table and forest plot shows number of infected males and total number of infected COVID-19 cases in 27 studies. The random effects model, which accounts for variance across reports, indicated no statistical difference (0.52 95\% Confidence Interval $(\mathrm{Cl})=0.50,0.53, \mathrm{p}=0.12)$. 


\begin{tabular}{|c|c|c|c|c|}
\hline \multirow[b]{2}{*}{ Source } & \multicolumn{2}{|r|}{ Males } & \multicolumn{2}{|c|}{ Females } \\
\hline & ITU & Total & ITU & Total \\
\hline China, 24/02/2020 (6) & 35 & 35 & 17 & 17 \\
\hline China, 07/02/2020 (8) & 22 & 75 & 14 & 63 \\
\hline France, $23 / 03 / 2020(10)$ & 190 & 2998 & 95 & 3380 \\
\hline Spain, $20 / 03 / 2020(18)$ & 807 & 16444 & 323 & 16363 \\
\hline Sweden, $26 / 03 / 2020$ (22) & 186 & 1937 & 69 & 1763 \\
\hline $\begin{array}{l}\text { Fixed effect model } \\
\text { Random effects model } \\
\text { Heterogeneity: } I^{2}=0 \%, \tau^{2}=\end{array}$ & & 21489 & & 2158 \\
\hline
\end{tabular}

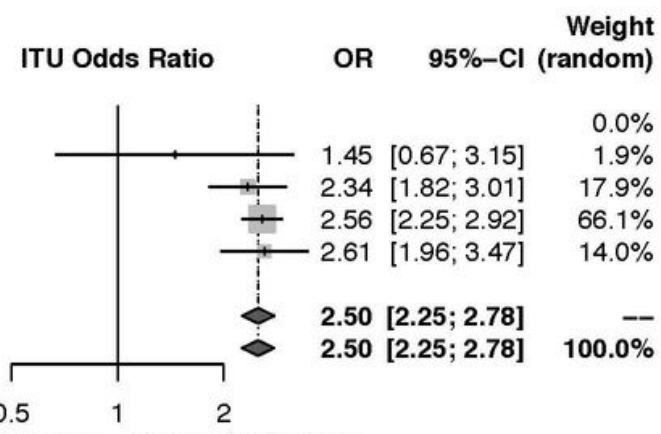

Higher risk for women Higher risk for men

\section{Figure 3}

Male sex is associated with a significantly increased risk for ITU admission within COVID-19 patients. Table and forest plot shows number of ITU admissions and total number of infected COVID-19 cases for each sex. Odds Ratio $(\mathrm{OR})=2.50 ; 95 \%$ Confidence Interval $(\mathrm{Cl})=2.25,2.78 ; \mathrm{p}=7.3 \mathrm{e}-64$ for random effects model, pooled across $n=5$ reports with complete data on COVID- 19 cases and ITU admissions in males and females.

\begin{tabular}{|c|c|c|c|c|c|c|c|c|}
\hline \multirow{2}{*}{$\begin{array}{l}\text { Source } \\
\text { China, 11/02/2020 (7) }\end{array}$} & \multicolumn{2}{|c|}{ Males } & \multicolumn{2}{|c|}{ Females } & Mortality Odds Ratio & OR & \multicolumn{2}{|r|}{$\begin{array}{l}\text { Weight } \\
\text { andom) }\end{array}$} \\
\hline & 653 & 22981 & 370 & 21691 & $\div$ & 1.69 & {$[1.48 ; 1.92]$} & $14.5 \%$ \\
\hline Denmark, 26/03/2020 (9) & 24 & 1102 & 10 & 749 & & 1.65 & {$[0.78 ; 3.46]$} & $2.6 \%$ \\
\hline France, $23 / 03 / 2020(10)$ & 94 & 2998 & 67 & 3380 & $\longrightarrow$ & 1.60 & {$[1.17 ; 2.20]$} & $8.4 \%$ \\
\hline Germany, 17/03/2020 (11) & 20 & 7897 & 11 & 6010 & & 1.38 & {$[0.66 ; 2.89]$} & $2.6 \%$ \\
\hline Iran, $15 / 03 / 2020$ (12) & 503 & 8545 & 350 & 6446 & + & 1.09 & {$[0.95 ; 1.25]$} & $14.1 \%$ \\
\hline Italy, 01/02/2020 (13) & 2139 & 20686 & 890 & 14378 & + & 1.75 & {$[1.61 ; 1.90]$} & $15.9 \%$ \\
\hline Netherlands, 19/03/2020 (14) & 133 & 2330 & 79 & 2394 & + & 1.77 & {$[1.33 ; 2.36]$} & $9.3 \%$ \\
\hline Portugal, 24/03/2020 (16) & 30 & 1409 & 13 & 1586 & & 2.63 & {$[1.37 ; 5.07]$} & $3.2 \%$ \\
\hline South Korea, 27/03/2020 (17) & 75 & 3638 & 64 & 5694 & - & 1.85 & {$[1.32 ; 2.59]$} & $7.9 \%$ \\
\hline Spain, 20/03/2020 (18) & 828 & 16444 & 498 & 16363 & + & 1.69 & {$[1.51 ; 1.89]$} & $15.0 \%$ \\
\hline Sweden, $26 / 03 / 2020$ (22) & 67 & 1937 & 43 & 1763 & 7 & 1.43 & {$[0.97 ; 2.11]$} & $6.7 \%$ \\
\hline Saudi Arabia, 23/03/2020 (27) & 0 & 266 & 0 & 296 & & & & $0.0 \%$ \\
\hline $\begin{array}{l}\text { Fixed effect model } \\
\text { Random effects model }\end{array}$ & & 90233 & & 80750 & $\stackrel{\vdots}{\circ}$ & $\begin{array}{l}1.62 \\
1.60\end{array}$ & $\begin{array}{l}{[1.54 ; 1.71]} \\
{[1.41 ; 1.82]}\end{array}$ & $100 . \overline{\%}$ \\
\hline \multirow{2}{*}{\multicolumn{3}{|c|}{ Heterogeneity: $I^{2}=74 \%, \tau^{2}=0.0255, p<0.001$}} & & & T & & & \\
\hline & & & & & 0.5 & 5 & & \\
\hline
\end{tabular}




\section{Figure 4}

Male sex is associated with a significantly increased risk for mortality within COVID-19 patients. Table and forest plot shows number of deaths and total number of infected COVID-19 cases for each sex. Odds Ratio $(\mathrm{OR})=1.60 ; 95 \%$ Confidence Interval $(\mathrm{Cl})=1.41,1.82 ; \mathrm{p}=7.4 \mathrm{e}-13$ for random effects model, $\mathrm{n}=12$ reports with complete data on COVID-19 cases and mortality in males and females.

\section{Supplementary Files}

This is a list of supplementary files associated with this preprint. Click to download.

- SupplementaryMaterial180420.docx 